\title{
A simple Bird Sensitivity to Oil Index as a management tool in coastal and marine areas subject to oil spills when few biological information is available
}

\author{
A.F. Romero*, M. Oliveira, D.M.S. Abessa \\ São Paulo State University (UNESP Campus do Litoral Paulista), Center of Investigation on Aquatic Ecotoxicology and Pollution (NEPEA), Praça Infante Dom Henrique, s/ \\ n. São Vicente, São Paulo, Brazil
}

\section{A R T I C L E I N F O}

\section{Keywords:}

Birds

Behavior

Feeding

Nesting

ESI maps

Oil spill

\begin{abstract}
A B S T R A C T
This study sought to develop a simple index for ranking birds' environmental sensitivity to oil in which birds are used as biological indicators. The study area consisted of both the Santos Estuarine System (SES), and the Laje de Santos Marine State Park (LSMSP), located in Southeastern Brazil. Information on the bird species and their feeding and nesting behaviors were obtained from the literature and were the basis of the sensitivity index created. The SES had a higher number of species, but only about $30 \%$ were found to be highly sensitive. The LSMSP presented a much lower number of species, but all of them were considered to be highly sensitive to oil. Due to its simplicity, this index can be employed worldwide as a decision-making tool that may be integrated into other management tools, particularly when robust information on the biology of birds is lacking.
\end{abstract}

\section{Introduction}

Oil spills have been recurrent worldwide and have caused varying degrees of damage to marine and coastal ecosystems (Gundlach and Hayes, 1978). In the vicinities of potential sources of oil, such as ports, refineries, vessel routes, oil terminals, and oil rigs, both marine organisms and their habitats are permanently at risk of being affected by oil spills (Gundlach and Hayes, 1978). When marine and coastal environments are subjected to oil spills, environmental recovery may be slow. According to reports on affected mangrove forests, recovery may takes years or even decades (Burns et al., 1993, 1994; Kingston, 2002; Santos et al., 2012). In an attempt to establish guidelines for quick and successful responses to oil spills, the National Oceanic and Atmospheric Administration (NOAA) developed Environmental Sensitivity Index (ESI) maps. These maps include shoreline classifications according to sensitivity to oil. The ESI itself was first proposed by Gundlach and Hayes (1978). It classifies coastal environments into different environmental sensitivity categories based on physical and geomorphological characteristics such as slope, wave exposure, and grain size. This classification was expanded by the NOAA to include biological and socioeconomic characteristics of the shoreline environments in addition to the physical parameters (NOAA, 2002). Information on sensitivity to oil is required if priority protection efforts are to be established; it is also essential when choosing the most appropriate response strategy during oil spill emergencies.

Emergency response measures should be carefully outlined in a contingency plan in order to minimize the impacts of oil on coastal and marine environments (Romero and Abessa, 2014). A contingency plan usually provides information on hazard identification, vulnerability analysis, risk assessment, and response actions. An oil spill contingency plan should present three sections: (1) a strategy section; (2) an action and operations section; and (3) a data directory containing all relevant maps, resource lists, and data sheets required to support an oil spill response effort and to allow the response to be carried out according to an agreed-upon strategy (IPIECA, 2000). A good contingency plan provides a prompt response to an oil spill.

Birds are highly vulnerable to oil spills; however, the sensitivity of a given species depends on a number of characteristics, from species behavior to biology (King and Sanger, 1979; Wiens et al., 1984; Burger, 1993; Speich et al., 1991; Williams et al., 1994; Wiens and Parker, 1995; Begg et al., 1997). When a bird is oiled, it essentially may be affected by two types of impacts: physical impacts and/or toxic impacts (IPIECA, 2016; Kennish, 1992; NOAA, 2002). Physical impacts are generally caused by heavy oils, which cover the animal and remove the waterproofing of their feathers, resulting in a loss of insulation and buoyancy (Kennedy, 1970; Peakall et al. 1982; Fry and Lowenstine, 1985; Islan and Tanaka, 2004). Toxic effects are largely caused by light oils, especially when spills are confined to limited areas. These oils have

\footnotetext{
* Corresponding author.

E-mail addresses: agatafr@gmail.com (A.F. Romero), dmabessa@clp.unesp.br (D.M.S. Abessa).
} 
more soluble and volatile components that may be directly absorbed via dermal contact, through the inhalation of hydrocarbon saturated vapors, or through the ingestion of contaminated food or water, all of which may cause a range of sublethal effects (Clark and Brown, 1977) such as liver damage and a decrease in the number of viable eggs (Grau et al., 1977; IPIECA, 2016; NOAA, 2002; Velando et al., 2007). Furthermore, these effects can increase mortality rates, and the aggregate effect of these consequences may produce negative alterations at the population level or the community level (GESAMP, 1980).

The mortality of oiled birds is a clearly visible impact of oil spills. Due to their position on the food chain, birds have been considered suitable indicators of the health and conservation statuses of ecosystems (Grant, 1991; Koskimies, 1979). Some marine and coastal birds establish breeding colonies, which have a substantial influence on local patterns of marine nutrient cycling and energy flows (Golovkin, 1968; Tuck, 1961). Birds tend to occur in highly productive ecosystems and may consume $22 \%$ to $27 \%$ of the annual production of small fishes (Wiens and Scott, 1975). Both the relative abundance and the presence of different groups of birds in the environment are thought to be important tools in environmental monitoring studies. The conservation statuses of ecosystems can be measured by factors such as changes in behavior, alterations to the size and/or structure of populations or communities, and amounts of biomass (Koskimies, 1979). Estimating birds' sensitivity to oil is therefore very important for providing information on the risks that oil spills create for this taxonomic group (Begg et al., 1997) and for the ecosystem as a whole. King and Sanger (1979) suggest that the establishment of a sensitivity index for birds could be a useful management tool with a range of applications. These authors proposed the first sensitivity index for birds: the Oil Vulnerability Index (King and Sanger, 1979). Later, Speich et al. (1991) developed a bird sensitivity index known as the Bird Oil Index and applied it to Puget Sound, a coastal area located in Washington State in the US. The US Coast Guard incorporated this index into oil spill response maps. The Bird Oil Index created by Speich et al. (1991) considers a range of information on bird behavior, population characteristics, and seasonal occurrences in the region. Other indices were further proposed (Anker-Nilssen, 1987; Begg et al., 1997; Camphuysen, 1989; Camphuysen and Leopold, 1998; Tasker and Pienkowski, 1987; Webb et al., 1995; Wiese and Ryan, 2003; Williams et al., 1994), but they basically represented adaptations of those indices established by King and Sanger (1979) and/or Speich et al. (1991). However, all of the detailed information necessary to calculate those indices may not always be accessible, especially in megadiverse areas, such as the coasts of tropical and subtropical regions. A lack of information may therefore hinder the use of this index and consequent coastal classification. In the current study, we provide a simple index for ranking environmental sensitivity to oil using birds as indicators, and apply it to two sites with different environmental and biological characteristics in order to assess its functionality. We have established a sensitivity ranking that considers the ecological niches occupied by all of the species identified, and we have created a set of symbols to represent the different levels of sensitivity on ESI maps.

\section{Materials and methods}

\subsection{Description of study area}

The study area is located on the central coast of São Paulo State in Southeastern Brazil (Fig. 1). It includes the Santos Estuarine System (SES) and the Laje de Santos Marine State Park (LSMSP). The SES is approximately $160 \mathrm{~km}^{2}$ in size and includes two main estuarine channels (the Santos Channel and São Vicente Channel), a major bay (the Santos Bay), and a series of small inlets, creeks, and estuarine islands. The coastal ecosystems in this region are dominated by mangrove swamps and salt marshes, as well as by rocky reefs, sand and mud flats, sheltered and semi-sheltered sandy beaches, and other types of habitats.
This area experiences intense anthropic influence, including the presence of a major industrial complex (including a major oil refinery, a large steel plant and several fertilizer and petrochemical plants), urban areas, and the Port of Santos, the largest port in Latin America. Due to these factors, part of the studied area is considered to be highly polluted (Abessa et al., 2008; Lamparelli et al., 2001). The LSMSP ( $24^{\circ} 19^{\prime}$ S, $46^{\circ} 11^{\prime} \mathrm{W}$ ) is located approximately $42 \mathrm{~km}$ from the coast and is formed by a main rocky islet and some rocky shores and reefs. The LSMSP is the only marine state park in São Paulo and is considered a hot spot for marine biodiversity. This islet is inhabited primarily by coastal and pelagic seabirds (Campos et al., 2004).

\subsection{Determining bird sensitivity}

Information on the birds of the study sites was obtained from the literature, including technical briefs, books, scientific papers, and academic reports containing information on different species, and, if possible, their distribution within the region. The survey was initially focused on collecting data on which bird species inhabit or occur in the SES and the LSMSP. The species found were then divided according to groups accepted by the National Oceanic and Atmospheric Administration, or the NOAA (2002) and the Brazilian Ministry of the Environment, or the MMA (2004): gulls/terns, pelagic birds, diving birds, waterfowls, wading birds, shorebirds, raptors, passerine birds, and non-passerine birds.

The purpose of the index is to classify different bird species according to their sensitivity to oil in the case of a hypothetical oil spill. Thus, the Bird Sensitivity to Oil Index (BSOI) was defined qualitatively based on the nesting and feeding behaviors of the birds found in the study area. These aspects were selected because they indicate the type and intensity of the contact of the birds with the oil spread on the water surface, after and oil spill. The information on the birds was obtained from such books as The Avis Brasilis - Field Guide to the Birds of Brazil and The Handbook of the Birds of the World (Hoyo et al., 1992; Sigrist, 2009) and other publications. Feeding behavior was defined according to the intensity of the species' contact with water: "no contact with water" (low sensitivity), "contact with surface water" (moderate sensitivity), and "diving" (high sensitivity). Nesting behavior was defined according to the distance between the respective species' nests and water. The classes established for nesting behavior were "no contact with water" (low sensitivity), "nest near water" (moderate sensitivity), and "nest in water/flooded area" (high sensitivity). The low, moderate, and high sensitivity levels for feeding and nesting behaviors were then crossed in a qualitative table in order to generate the Bird Sensitivity to Oil Index (Table 1).

The "Slight Sensitivity" category is applied to species that do not experience any contact with water during nesting or feeding behaviors. The "Moderate Sensitivity" category reflects species which nest near water or experience contact with surface water when feeding. Species that nest near water and experience contact with surface water during feeding were classified as having "Severe Sensitivity." The Highest BSOI category, "Extreme Sensitivity", is applied to species that dive or/and nest in water or in flooded areas.

\subsection{Creating symbols for the Bird Sensitivity to Oil Index}

In order to integrate the BSOI into ESI maps so that they may be of use in the oil spill response planning process, we developed a set of images to represent the different bird sensitivity categories. This study used the bird point symbols created by the NOAA (2002), which are the same symbols used to represent biological resources in Brazilian protocols (MMA, 2004). A small colored circle is placed above the bird point symbols used to represent each group of species, and the categories are indicated by different colors: blue represents Slight Sensitivity, yellow represents Moderate Sensitivity, orange represents Severe Sensitivity, and red represents Extreme Sensitivity (Fig. 2). 


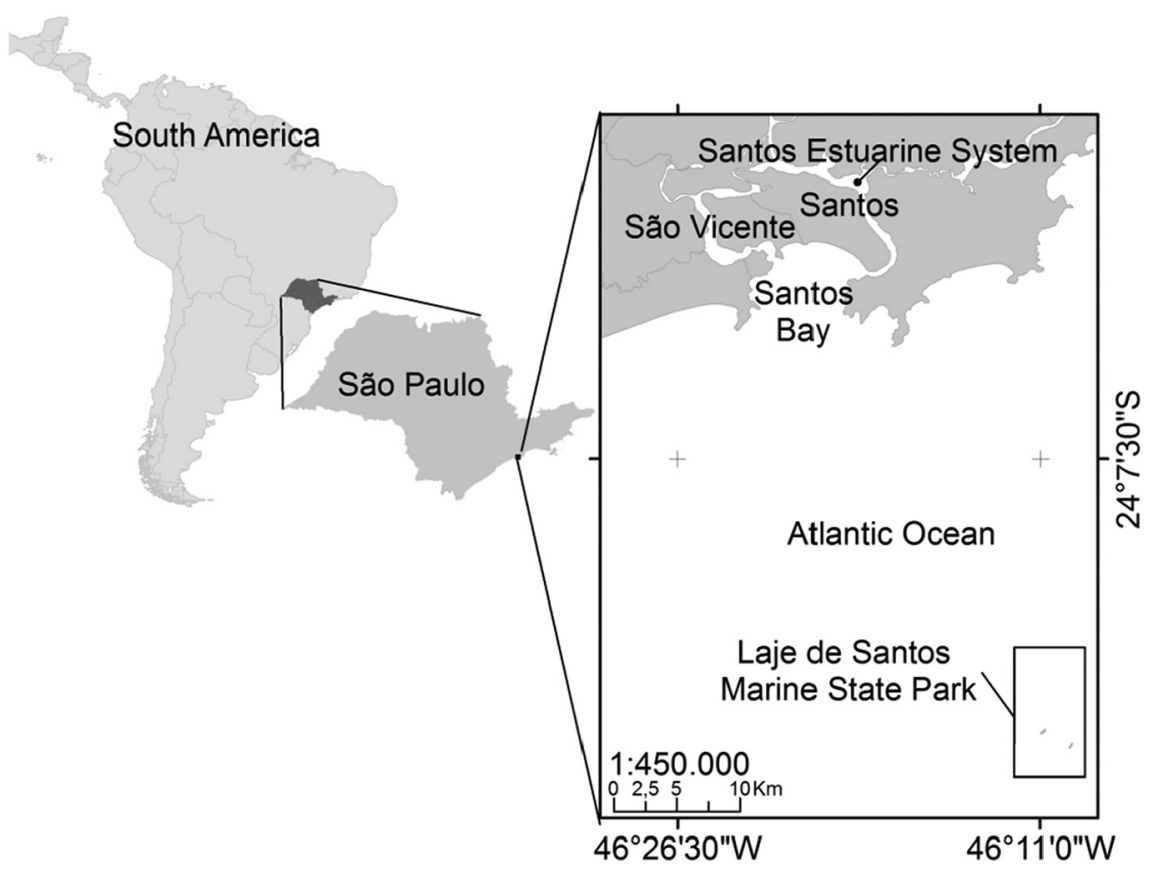

Fig. 1. Location of the study area.

Table 1

Crossing the sensitivity of nesting and feeding behaviors in order to generate the Bird Sensitivity to Oil Index (BSOI).

\begin{tabular}{llll}
\hline Feeding/nesting & $\begin{array}{l}\text { No contact with } \\
\text { water }\end{array}$ & Near water & $\begin{array}{l}\text { On water/flooded } \\
\text { area }\end{array}$ \\
\hline $\begin{array}{l}\text { No contact with water } \\
\begin{array}{l}\text { Contact with water } \\
\text { surface }\end{array}\end{array}$ & $\begin{array}{l}\text { Slight } \\
\text { Moderate }\end{array}$ & $\begin{array}{l}\text { Moderate } \\
\text { Severe }\end{array}$ & $\begin{array}{l}\text { Extreme } \\
\text { Extreme }\end{array}$ \\
& Extreme & Extreme & Extreme \\
\hline
\end{tabular}

\section{Slight Sensitivity}

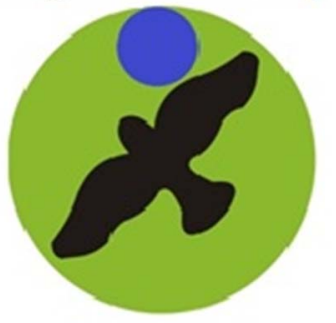

\section{Severe Sensitivity}

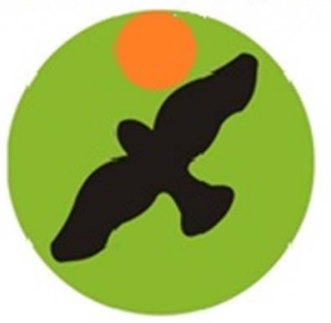

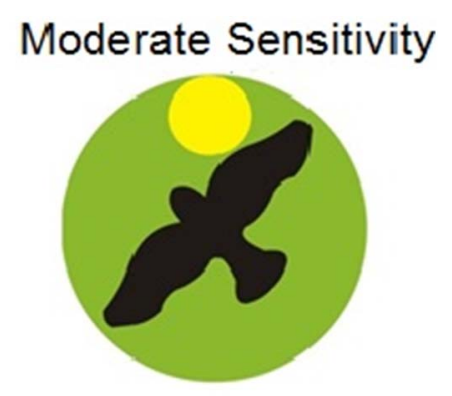

Extreme Sensitivity

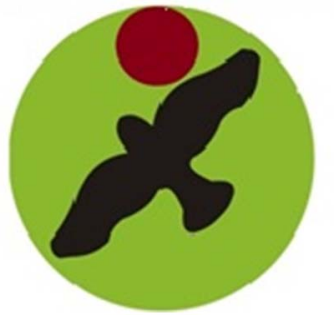

Fig. 2. Representation of the Bird Sensitivity to Oil Index using an NOAA bird point symbol. (For interpretation of the references to color in this figure legend, the reader is referred to the web version of this article.)

\section{Results}

In this survey, 261 species were found to be occurring in or inhabiting the whole study area (244 species in the SES and 17 in the

LSMSP). To summarize, 144 species were classified as exhibiting Slight Sensitivity, 20 were classified under Moderate Sensitivity, 52 were classified under Severe Sensitivity, and 45 were found to exhibit Extreme Sensitivity. The BSOI categories for each of the 261 species are listed in the supplementary material.

According to the data collected, 244 bird species are found in the SES. Of these, 144 were ranked as exhibiting Slight Sensitivity, while 20 exhibited Moderate Sensitivity, 46 exhibited Severe Sensitivity, and 34 exhibited Extreme Sensitivity. The SES, an estuarine region, is inhabited by species from most bird groups, with the exception of pelagic birds. Meanwhile, 17 bird species were found to occur in the LSMSP. Of these, 6 were ranked as exhibiting Severe Sensitivity and 11 were ranked under Extreme Sensitivity. No LSMSP species were found to exhibit Slight or Moderate Sensitivity. The species found in this region belong to gull/tern group and the pelagic bird group.

The two areas considered in this study exhibited differences in terms of bird habits. The SES presented a much higher number of bird species, but most were ranked in the Slight and/or Moderate Sensitivity categories (164 species, or 67.2\%); however, 80 species were classified in the Severe or Extreme BSOI categories. Meanwhile, the LSMSP was found to be home to fewer bird species, but all of them were found in aquatic habits and were ranked in the Severe or Extreme BSOI categories; in other words, all species found in the LSMSP would be seriously affected by an oil spill.

A GIS software was used to create maps with this sensitivity index. The maps of birds' sensitivity to oil spills with the index developed in this study are represented in Supplementary Material Maps.

\section{Discussion}

According to the results, the two studied sites would be differently affected during an oil spill, and the effects on marine birds would be distinct. In the mangrove areas from the SES, 80 species would be severely affected by an oil spill (those exhibiting Severe or Extreme Sensitivity), representing $32.8 \%$ of all listed birds for this region. Thus, an oil spill reaching the SES would negatively affect a large number of bird species. On the other hand, all the species from the island site (LSMSP) would be drastically affected in case of an oil spill reaching that region.

The SES presented a high number of bird species despite the high 
levels of pollution and other anthropic impacts reported in this area (Abessa et al., 2008; Lamparelli et al., 2001). The abundance of birds in the SES is associated with the mangrove swamps located therein. Mangroves are widely known by their ecological importance, as providing protection for maturing offspring; stabilization of sediments and protection of shorelines from erosion; water and atmospheric quality improvements; filtering and assimilation of pollutants from upland runoff; basis of a complex marine food chain; and creation of critical habitat for fisheries and coastal bird populations (Lugo and Snedaker, 1974). The local mangrove swamps are productive ecosystems that are rich in nutrients and which provide habitats for both resident and migratory birds (Olmos et al., 2003). However, their NOAA ESI ranking is a 10 - the highest environmental sensitivity to oil. In this sense, despite the negative effects an oil spill will produce on the birds associated to mangroves, these ecosystems should be prioritized, as they are already considered highly sensitive to oil. According to the national forest code (Brasil, 2012), mangrove forests are legally protected (namely "permanent protection areas").

Meanwhile, the Laje de Santos Marine State Park shorelines are ranked as ESI 1 and 2 - the lowest environmental sensitivity to oil -, but the area is still considered an important region for marine birds (Campos et al., 2004). The LSMSP is the only place in Brazil where Sterna hirundinace, Thalasseus maximus, and Thalasseus eurygnathus breed (Campos et al., 2004), representing also a nesting site for the Brown Bobby (Sula leucogaster) and the Kelp Gull (Larus dominicanus) and consisting of an important feeding and resting site for marine birds. In addition, the park contains high marine biodiversity, and manylocal marine organisms are food resources for birds (Tebecherani et al., 2009).

In the LSMSP, however, $100 \%$ of the species would be greatly affected by an oil spill (all exhibit Severe or Extreme Sensitivity), a factor which would make a spill at that location a highly critical event in terms of effects on birds. An oil spill that reached the LSMSP during the reproductive period of the common tern (Sterna hirundinace), for example, could decimate most of the juveniles. If the offspring is lost, the breeding season will end up unsuccessful, with negative implications to the entire population of such species. Moreover, as the oil may cause mass mortality of fish and invertebrates, an oil spill may cause dramatic reduction of food availability to marine birds, with negative consequences for their health and survival. The presence of the oil slick on the water surface is also a factor that may interfere on the visualization of food (fish schools, for example) as most of marine birds feed based on visual location of preys (Martínez-Abraín and Oro, 2004).

As the marine birds inhabiting the island area (LSMSP) are top predators that feed mainly on fish, squids and zooplankton and participate on the regulation of the bottom levels of the marine food chain (Montevecchi and Myers, 1995), disturbances on their populations are expected to interfere on the structure and function of inferior trophic levels of the food chain, with unknown ecological effects. Therefore, island environments, as those represented by the LSMSP, are critical not only for marine birds but also for the marine conservation, and should be considered highly vulnerable to the oil.

Bird mortality during oil spills has been extensively studied and reported (Burger, 1997; García et al., 2003; Henkel et al., 2014; Piatt et al., 1990; Wiens et al., 1996). The Exxon Valdez tanker spill in Alaska, the Prestige tanker spill in La Coruña, Spain, and the Amoco Cadiz supertanker spill along the coast of Brittany, France all represent examples of how oil spills can affect and kill large numbers of birds around the world. Bird mortality after an oil spill is difficult to measure due to the underestimated number of oiled bird carcasses found on the beach. Different authors may have presented different bird mortality rates for birds, but there is no question that oil spills are damaging to bird populations (Burger, 1997; Flint et al., 1999; García et al., 2003).

Information on the effects and/or influence of oil on terrestrial birds such as passerines, non-passerines, and raptors is extremely scarce. These birds often have less contact with water; therefore, some of their respective species were classified as exhibiting only slight or moderate sensitivity in this study. However, some species of these groups were classified as exhibiting severe or extreme sensitivity. The raptors group was ranked in low sensitivity categories due to the species' more terrestrial behaviors. However, Zuberogoitia et al. (2006) showed that some species, such as the peregrine falcon Falco peregrinus, may also be affected by oil spills. According to the author, F. peregrinus and other species of raptors prey on aquatic birds. In addition, the peregrine falcon was found to be a predator to $10.7 \%$ of the species that were affected by the Prestige oil spill in Spain (García et al., 2003). This kind of exposure to oil can expose species to sublethal levels of pollutants that affect species' breeding activities.

The non-passerine bird group is most commonly represented by terrestrial species, but there are some cases in which members of this group have contact with water. In these cases, the respective species were ranked as exhibiting Severe or Extreme Sensitivity in this study. Overall, it is important to note that species which feed on or close to the shore and which breed on the beach tend to be more significantly impacted by oil (Wiens et al., 1996).

Our study also showed that, although species were grouped by morphology and behavior, some groups are very large. Certain groups, such as the non-passarines, contain different families, and these families received different sensitivity rankings. Therefore, sensitivity should be analyzed at the species level whenever possible in order to avoid misleading results when ranking bird species according to the BSOI.

Other sensitivity indices for marine birds have been developed in the past, particularly in Europe. King and Sanger (1979) firstly proposed an oil vulnerability index (OVI) for marine birds, which comprised 20 factors affecting marine bird species; this OVI required information on the biology and population sizes of each species, such as breeding range sizes, lengths of migration routes, winter range size, marine orientation, population size, productivity, habits, threats, seasonality, among others. Camphuysen (1989) used the OVI from King and Sanger (1979) to quantify the oil vulnerability of all regularly occurring species of seabirds in the North Sea. Further, Camphuysen and Leopold (1998) narrowed down the number of 'survival factors' to 14. Tasker and Pienkowski (1987) proposed three categories of oil pollution vulnerability (very high, high and moderate) to 37 North Sea species of marine birds, based on three key characteristics: 1) time spend on surface water; 2) North Sea importance to large proportion of the global population of the species; 3) global rarity of the species. The vulnerability rating was combined with information on the marine distribution of the bird species. Anker-Nilssen (1987) assessed 17 factors that make a species vulnerable to oil pollution, at both individual and population levels. With the help of expert judgement, Speich et al. (1991) allocated scores to 14 factors (in three groups) in order to calculate a Bird Oil Index (BOI) for Puget Sound. Begg et al. (1997) employed the Area Vulnerability Score (AVS) which attempted to quantify the impact that oil pollution in a given area would have on marine bird populations, based also on the OVIs previously proposed by King and Sanger (1979) and Speich et al. (1991). Wiese and Ryan (2003), in a study conducted in Newfoundland (Canada) used a Winter OVI (WOVI) based on the criteria outlined by King and Sanger (1979) and adapted by Camphuysen (1998), taking into account the birds' distribution, behavior and exposure to oil. Webb et al. (1995) and Williams et al. (1994) used a different approach to assess seabird sensitivity to surface pollutants. Rather than rely on expert judgement, these authors based their scoring procedure on data derived from surveys and scientific studies, but also requiring population information, together with other aspects such as behavior; reproductive potential; and reliance on the marine environment.

In general, the marine bird sensitivity indices found in literature determine species sensitivity to oil pollution using several biological and physical factors such as reproductive potential, population size, breeding distribution, and seasonal exposure in marine habitats. Due to the large amount of information required to generate these indices, 
Wiens et al. (1984) concluded that single studies are not complete enough to generate information on all of these factors. King and Sanger (1979) also stated that there was not enough information to classify the species they studied according to the existing index. In addition, the existing indices require a high amount of information on the existing marine bird species and thus they could provide a suitable assessment of the vulnerability to oil when all the necessary information is available. This system could be considered subjective by some experts. The authors also suggested that further research would be able to review and refine the scores, and that a considerable amount of additional data should be generated in order to refine the indices. However, the main limitation to such indices relies on their application in regions where the biology of the marine birds is poorly known, such as highly diverse tropical and subtropical coastal zones. To such sites, a simple index may be necessary to establish the marine birds sensitivity to oil until detailed information is obtained and a more robust index can be used.

In our study, the criteria established were found to be useful. They allowed for the development of a simple and reliable index (the BSOI). This index was successfully applied to all of the bird species occurring in the area, and it showed that different environments may be affected differently if oiled. Mangroves are home to many more species, though few of these species are severely or extremely sensitive to oil. The island environment harbored fewer species, but all of them were found to be highly sensitive.

In light of these findings, this study contributes to the development of a solution for classifying birds' sensitivity to oil and could ideally be applied at different sites worldwide.

Our results also show that the classic ESI may not provide sufficient information for protecting species and ecosystems: though the ESI considers mangroves to be more sensitive (ESI 10) than exposed rocky shores (ESI 1 and 2), a comparison of the two study regions based on their BSOI categories showed that, if an oil spill were to occur, the LSMSP species would be much more negatively affected than the ESI maps suggest. Both areas studied herein can be considered highly sensitive, but for different reasons: the SES is sensitive because a large number of birds would be negatively affected by an oil spill, because its mangroves can be considered a hot spot for bird biodiversity, and because they are legally protected in Brazil and are therefore already defined as environmentally at-risk regions. Meanwhile, the LSMSP is a sensitive site because all of the bird species present exhibit high sensitivity to oil and because the entire site already consists of a protected area (Marine State Park) dedicated to biodiversity conservation, an area which is at-risk by definition.

In this study, we demonstrate that the Bird Sensitivity to Oil Index (BSOI) provides a basis for ESI maps and oil spill response planning: it can guide protection efforts to areas inhabited by more vulnerable species (areas such as the Laje de Santos Marine State Park) or to hot spots (such as the Santos Estuarine System).

The BSOI proposed in this study can be applied in other regions of world and to a wide range of bird species. This index can be further improved by incorporating more ecological information, such as seasonality, type of oil, and ICUN status in order to more realistically assess environmental sensitivity to oil; further studies would be required to achieve this goal. Similarly, other biological groups may be incorporated into the emergency action planning (such as fish, invertebrates, mammals, plants, or reptiles). This information would provide a better understanding of each environment's sensitivity to oil.

\section{Conclusion}

When different bird groups are compared, we can conclude that, in general, marine and coastal species as gulls/terns, pelagic birds, shorebirds, wading birds, and waterfowls tend to be more sensitive to oil spills and thus exhibit severe to extreme sensitivity according to the Bird Sensitivity to Oil Index (BSOI). On the other hand, few species of terrestrial birds (non-passerines) presented feeding or nesting behavior directly involving water that would rank them as exhibiting high sensitivity on the BSOI. Some groups of birds are consistently more sensitive than others, but this was not the rule, as was seen in the case of the non-passerine group.

The two areas studied herein present different sensitivity levels according to the BSOI. While the Santos Estuarine System harbors a greater number of bird species, only about $30 \%$ are considered to be severely or extremely sensitive; however, because the area itself is a hot spot for bird biodiversity, it can be considered to be extremely sensitive overall. An area presenting much fewer species, such as the Laje de Santos Marine State Park, can be considered highly sensitive to oil because $100 \%$ of the 17 bird species found therein were classified as severely or extremely sensitive according to the BSOI.

The Bird Sensitivity to Oil Index is widely applicable, particularly when low information on the biology and population of marine birds is available. This index can be used provisionally, until detailed information on the species is obtained and a more complex index can be employed in substitution. The BSOI can be used as a decision-making tool and can also be combined with other tools such as ESI maps in order to help to define priority areas for protection in case of an oil spill. It is important to note that biological sensitivity indices do not always agree with the ESI, a factor which indicates the need to consider two indices in an integrated way in order to determine which areas are a priority for protection.

\section{Acknowledgements}

This work was supported by the São Paulo Research Foundation FAPESP [grant number 2012/14508-3]; and the National Research Council - CNPq [grants number 308649/2011-7 and 311609/2014-7]. The authors would like to thank Danielle Deremo Cosimo of Superior Traduções for editing the grammar and language of the article.

\section{Appendix A. Supplementary data}

Supplementary data to this article can be found online at https:// doi.org/10.1016/j.marpolbul.2017.12.008.

\section{References}

Abessa, D.M.S., Carr, R.S., Sousa, E.C.P.M., Rachid, B.R.F., Zaroni, L.P., Gasparro, M.R. Pinto, Y.A., Bícego, M.C., Hortellani, M.A., Sarkis, J.E.S., Muniz, P., 2008. Integrative ecotoxicological assessment of contaminated sediments in a complex tropical estuarine system. In: Hofer, T.N. (Ed.), Marine Pollution. New Research, Nova Science Publishers Inc., New York, pp. 125-159.

Anker-Nilssen, T., 1987. Metoder til konsekvensanalyser olje/sjøfugl. Viltrapport 44, $1-114$.

Begg, G.S., Reid, J.B., Tasker, M.L., Web, A., 1997. Assessing the sensitivity of seabirds to oil pollution: sensitivity to spatial scale. Colon Waterbirds 20 (2), 339-352.

Brasil, 2012. Lei ${ }^{\circ} 12.651$, de 25 de maio de 2012. http://www.planalto.gov.br/ccivil 03/ ato2011-2014/2012/lei/L12651compilado.htm.

Burger, A.E., 1993. Estimating the mortality of seabirds following oil spills: effects of spill volume. Mar. Pollut. Bull. 26 (3), 140-143.

Burger, J., 1997. Effects of oiling on feeding behavior of sanderlings and semipalmated ploves in New Jersey. Condor 99, 290-298.

Burns, K.A., Garrit, S.D., Levings, S.C., 1993. How many years until mangrove ecosystems recover from catastrophic oil spills? Mar. Pollut. Bull. 26 (5), 239-248.

Burns, K.A., Garrit, S.D., Jorissen, D., MacPherson, J., Stoelting, M., Tierney, J., YelleSimmons, L., 1994. The Galeta oil spill II. Unexpected persistence of oil trapped in mangrove sediments. Estuar. Coast. Shelf S. 38, 349-364.

Camphuysen, C.J., 1989. Beached-bird Surveys in the Netherlands 1915-1988; Seabird Mortality in the Southern North Sea Since the Early Days of Oil Pollution. Techn. Rapport Vogelbescherming. 1 Werkgroep Noordzee, Amsterdam (322 pp.).

Camphuysen, C.J., 1998. Beached-bird surveys indicate decline in chronic oil pollution in the North Sea. Mar. Pollut. Bull. 36 (7), 519-526.

Camphuysen, C.J., Leopold, M.F., 1998. Kustvogels, zeevogels en bruinvissen in het Hollandse kustgebied. NIOZ Report 1998-4, CSR Rapport 1998-2. Nederlands Instituut voor Onderzoek der Zee, Texel.

Campos, F.P., Paludo, D., Faria, P.J., Martuscelli, P., 2004. Aves insulares marinhas, residentes e migratórias, do litoral do Estado de São Paulo. In: Branco, J.O. (Ed.), Aves marinhas insulares brasileiras: bioecologia e conservação. Editora da UNIVALI, Itajaí, pp. 57-82.

Clark, R.C., Brown, D.W., 1977. Petroleum: properties and analyses in biotic and abiotic 
systems. In: Malins, D.C. (Ed.), Effects of Petroleum on Arctic and Subarctic Marine Environments and Organisms, v. 1. Academic Press, New York, pp. 1-89.

Flint, P.L., Fowler, A.C., Rockwell, R.F., 1999. Modeling bird mortality associated with the M/V citrus oil spill off St. Paul Island, Alaska. Ecol. Model. 117, 261-267.

Fry, D.M., Lowenstine, L.J., 1985. Pathology of common murres and Cassin's auklets exposed to oil. Arch. Environ. Contam. Toxicol. 14, 725-737.

García, L., Viada, C., Moreno, R., Carboneras, C., Alcalde, A., Gonzáles, F., 2003. Impacto de la marea negra del Prestige sobre las aves marinas. SEO/BirdLife, Madrid.

GESAMP (IMO/FAQ/UNESCO/WMO/IAEA/UN/UNEP Joint Group of Experts on the Scientific Aspects of Marine Pollution), 1980. Impact of oil and related chemicals and wastes on the marine environment. Reports and Studies GESAMP(50) (180 pp.).

Golovkin, A.N., 1968. The effect of colonial seabirds on development of the phytoplankton. Oceanology 7, 521-529.

Grant, M.C., 1991. Nesting densities, productivity and survival of breeding whimbrel Numenius-Phaeopus, in Shetland. Bird Study 38 (3), 160-169.

Grau, C.R., Roudybush, T., Dobbs, J., Wathen, J., 1977. Altered yolk structure and reduced hatchability of eggs from birds fed single doses of petroleum oils. Science 195, 779-781.

Gundlach, E.R., Hayes, M.O., 1978. Vulnerability of coastal environments to oil spill impacts. Mar. Technol. Soc. J. 12 (4), 18-27.

Henkel, L.A., Nevins, H., Martin, M., Sugarman, S., Harvey, J.T., Ziccardi, M.H., 2014. Chronic oiling of marine birds in California by natural petroleum seeps, shipwrecks, and other sources. Mar. Pollut. Bull. 79, 155-163.

Hoyo, J., Elliott, A., Sargatal, J., 1992. Handbook of the Birds of the World Vol:1 - Ostrich to Ducks. Lynx Edicions, Barcelona.

IPIECA, 2000. Guía para la planificación de contingências ante derrames de hidrocarburos em água. Série de informes de IPIECA. V. 2. pp. 28.

IPIECA, 2016. Impacts of oil spills on marine ecology. Good practice guidelines for incident management and emergency response personnel. IPIECA-IOGP Good Practice Guide Series. London/Brussels. Available from. http://www.ipieca.org/resources/ good-practice/impacts-of-oil-spills-on-marine-ecology-good-practice-guidelines-forincident-management-and-emergency-response-personnel/, Accessed date: 31 August 2017.

Islan, Md.S., Tanaka, M., 2004. Impacts of pollution on coastal and marine ecosystems including coastal and marine fisheries and approach for management: a review and synthesis. Mar. Pollut. Bull. 48, 624-649.

Kennedy, R.J., 1970. Directional water-shedding properties of feathers. Nature 227, 736-737.

Kennish, M.J., 1992. Ecology of Estuaries: Anthropogenic Effects. CRC Press, Boca Raton, FL.

King, J.G., Sanger, G.A., 1979. Oil vulnerability index for marine oriented birds. In: Bartonek, J.C., Nettleship, D.N. (Eds.), Conservation of Marine Birds of Northern North America, Wildlife Research Report 11. United States Department of the Interior Fish and Wildlife Service, Washington, pp. 227-239.

Kingston, P.F., 2002. Long-term environmental impact of oil spills. Spill Sci.Technol. B. 7 (1-2), 53-61.

Koskimies, P., 1979. Birds as a tool in environmental monitoring. Ann. Zool. Fenn. 26, 153-166.

Lamparelli, M.L., Costa, M.P., Prósperi, V.A., Bevilácqua, J.E., Araújo, R.P.A., Eysink, G.G.L., Pompeia, S., 2001. Sistema Estuarino de Santos e São Vicente. Relatório Técnico, São Paulo, CETESB (178 pp.).

Lugo, A.E., Snedaker, S.C., 1974. The ecology of mangroves. Annu. Rev. Ecol. Syst. 5, 39-64.

Martínez-Abraín, A., Oro, D., 2004. Ecology and behaviour of seabirds. In: Encyclopedia of Life Support Systems. EOLSS Publishers-UNESCO, Oxford, UK. http://www.eolss. net.

MMA (Ministério do Meio Ambiente), 2004. Especificações e normas técnicas para elaboração de cartas de sensibilidade ambiental para derramamentos de óleo.
Ministério do Meio Ambiente, Brasília, DF, Brasil.

Montevecchi, W.A., Myers, R.A., 1995. Prey harvest of seabirds reflect pelagic fish and squid abundance on multiple spatial and temporal scales. Mar. Ecol. Prog. Ser. $117,1-9$.

NOAA, 2002. National Oceanic Atmospheric Administration. Environmental Sensitivity Index Guidelines, Version 3.0. NOAA Technical Memorandum NOS OR\&R 11. Seattle: Hazardous Materials Response and Division, National Oceanic and Atmospheric Administration. available at: http://response.restoration.noaa.gov/sites/default/ files/ESI Guidelines.pdf, Accessed date: 31 August 2017.

Olmos, F., Silva e Silva, R., 2003. Guará: Ambiente, Flora e Fauna dos Manguezais de Santos-Cubatão. Editora Empresa das Artes, São Paulo, Brasil (216 pp.).

Peakall, D.B., Hallett, D.J., Bend, J.R., Foureman, G.L., Miller, D.S., 1982. Toxicity of Prudhoe Bay crude oil and its aromatic fractions to nestling herring gulls. Environ. Res. 27 (1), 206-215.

Piatt, J.F., Lensink, C.J., Butler, W., Kendziorek, M., Nysewander, D.R., 1990. Immediate impact of the Exxon Veldez oil spill on marine birds. Auk 107, 387-397.

Romero, Á.F., Abessa, D.M.S., 2014. Mapa de procedimentos de limpeza e ações de combate a derramamentos de óleo. Braz. J. Aquat. Sci. Technol. 18 (2), NB1-3. http://dx.doi.org/10.14210/bjast.v18n2.pNB1-3. Itajaí, ISSN 1983-9057.

Santos, L.C.M., Cunha-Lignon, M., Schaeffer-Novelli, Y., Cintrón-Molero, G., 2012. Long term effects of oil pollution in mangrove forest (Baixada Santista, Southeast Brazil) detected using a GIS-based multitemporal analysis of aerial photographs. Braz. J. Oceanogr. 60 (2), 159-170.

Sigrist, T., 2009. The Avis Brisilis Field Guide to the Birds of Brazil. Avis Brasilis Editora, São Paulo, Brasil.

Speich, S.M., Manuwal, D.A., Wahl, T.R., 1991. The bird/habitat oil index - a habitat sensitivity index based on avian utilization. Wildl. Soc. Bull. 19, 216-221.

Tasker, M.L., Pienkowski, M.W., 1987. Vulnerable Concentrations of Birds in the North Sea. Nature Conservancy Council, Peterborough Available from: www.vliz.be/ imisdocs/publications/261572.pdf.

Tebecherani, G.K., Pinto, A.P.B., Junior, Luiz, O.J. (orgs.), 2009. Laje de Santos: laje dos sonhos. Globo, São Paulo.

Tuck, L.M., 1961. The murres. Canadian Wildlife Service Monograph No. 1. In: Vermeer, K., Vermeer, R. (Eds.), Oil Threat to Birds on the Canadian West Coast. Canadian Field-Naturalist. 89. Queen's Printer, Ottawa, pp. 278-298 (Q0975).

Velando, A., Pérez, C., Alonzo- Alverez, C., 2007. Effects of acute exposure to heavy fuel oil from the Prestige spill on a seabird. Aquat. Toxicol. 84, 103-110.

Webb, A., Stronach, A., Tasker, M.L., Stone, C.J., 1995. Vulnerable Concentrations of Seabirds South and West of Britain. Joint Nature Conservation Committee, Peterborough (47 pp.).

Wiens, Parker, 1995. Effects of the Exxon Valdez oil spill on marine bird communities in Prince William Sound, Alaska. Ecol. Appl. 5 (4), 1069-1083.

Wiens, J.A., Scott, J.M., 1975. Model estimation of energy flow in Oregon coastal seabird populations. Condor 77 (4), 439-452.

Wiens, J.A., Glenn Ford, R., Heinemann, D., 1984. Information needs and priorities for assessing the sensitivity of marine birds to oil spills. Biol. Conserv. 28, 21-49.

Wiens, J.A., Crist, T.O., Day, R.H., Murphy, S.M., Hayward, G.D., 1996. Effects of the Exxon Valdez oil spill on marine bird communities in Prince William Sound, Alaska. Ecol. Appl. 6 (3), 828-841.

Wiese, F.K., Ryan, P.C., 2003. The extent of chronic marine oil pollution in southeastern Newfoundland waters assessed through beached bird surveys 1984-1999. Mar. Pollut. Bull. 46, 1090-1101.

Williams, J.M., Tasker, M.L., Carter, I.C., Webb, A., 1994. A method of assessing seabird sensitivity to surface pollutants. Ibis $137,147-152$.

Zuberogoitia, I., Martínez, J.A., Iraeta, A., Azkona, A., Zabala, J., Jiménez, B., Merino, R., Gómez, G., 2006. Short-term effects of the prestige oil spill on the peregrine falcon (Falco peregrinus). Mar. Pollut. Bull. 52, 1176-1181. 